1. Архицкая Е.В., Абаилдина М.Ш., Курченкова О.Р., Спасельникова А.В., Шмат Е.В. «Качество и безопасность молочного сырья - основа здоровья нации». Сборник научных трудов №5: «Наука и образование в жизни современного общества», том 10, часть 10, стр. 22.

2. ГОСТ Р 53436-2009 «Консервы молочные. Молоко и сливки сгущенные с сахаром. Технические условия» [Электронный ресурс]: - Режим доступа: http://vsegost.com/Catalog/48/48659.shtml

\title{
Батуева B.A. \\ Морфологические признаки присутствия вируса папилломы человека в слизистой оболочке верхних дыхательных путей
}

МУЗ ГБСМП

(Россия, Таганрог)

doi:10.18411/lj2016-4-06

Вирус папилломы человека (ВПЧ) - широко распространенный инфекционный агент, персистирующий в клетках базального слоя эпителия. На сегодняшний день известно более 150 типов вируса папилломы человека, принадлежащих к семейству Papillomaviridae [1]. Клиническое значение папилломавирусной инфекции определяется способностью ВПЧ видоизменять рост и дифференцировку клеток [2]. Морфологическими проявлениями этих изменений является увеличение числа клеток в апоптотическом состоянии и выраженные пролиферативные реакции эпителия.

Причастность вируса папилломы человека (ВПЧ) к возникновению рака некоторых локализаций доказана с высокой степенью достоверности с помощью молекулярно-биологических методов и эпидемиологических исследований. На сегодняшний день не вызывает сомнения вирусная этиология ювенильного респираторного папилломатоза гортани [3], который связывают с ВПЧ 6 и 11 типов. Имеются данные об участии ВПЧ в патогенезе носовых кровотечений $[4,5]$ и в морфогенезе инвертированной папилломы носа $[6,7]$.

В связи со сложностью и дороговизной специфических методов идентификации вируса папилломы человека (гибридизация in situ: PathoGene, ViraType и Southern blotting) для обнаружения ПВИ предложено использовать цитоморфологические методы исследования, выявляющие патогномоничные признаки присутствия ВПЧ на тканевом и клеточном уровнях. Специфические маркерные клетки многослойного плоского эпителия, пораженного ПВИ, - койлоциты - характеризуются определенным набором признаков. Это оксифильно окрашенные клетки с увеличенным или пикнотическим, гиперхромным ядром и выраженной зоной просветления вокруг ядра, получившей название «перинуклеарное гало». «Перинуклеарное гало» образуется вследствие выраженной вакуолизации цитоплазмы клеток, связанной с репликацией вируса.

Цель работы: установить степень информативности морфологического исследования биоптатов слизистой оболочки верхних дыхательных путей для выявления папилломавирусной инфекции.

Материалы и методы исследования: исследованию подвергались больные, у которых при гистологическом анализе удаленных во время хирургических вмешательств тканей выявлены косвенные признаки цитопатического действия вируса папилломы человека (ВПЧ): наличие койлоцитов (клеток - маркеров ПВИ), утолщение эпителиального пласта, признаки индуцированного ангиогенеза. Для доказательства наличия ПВИ проведено выявление ВПЧ методом полимеразной цепной реакции (ПЦР).

Мы наблюдали 25 больных (3 детей и 22 взрослых) с различными новообразованиями верхних дыхательных путей. 12 больных были подвергнуты хирургическому лечению по поводу одиночного кровоточащего полипа перегородки носа (6 человек, из которых у 2 операция произведена в связи с рецидивом после предыдущего удаления полипа), распространенного папилломатоза полости рта (1 больной), инвертированной папилломы полости носа (5 больных). 9 больным была произведена биопсия, позволившая уточнить диагноз и провести консервативное лечение по поводу папилломатоза носоглотки (1 больной), хронического гипертрофического ларингита (5 больных), гипертрофии язычной миндалины (3 
больных). У 4 больных выявлено наличие рака гортани, эти больные продолжили лечение в специализированном онкологическом стационаре.

Результаты: у 22 больных исследованных методом ПЦР выявлено наличие ВПЧ различных типов: у больных с кровоточащими полипами перегородки носа (как первичными, так и рецидивирующими) выявлен простой вирус папилломы человека, у больной с папилломатозом носоглотки - онкогенный вирус 33 типа, с папилломатозом полости рта - онкогенный вирус 6 типа, у больных с инвертированной папилломой носа - онкогенные вирусы 18, 31 и 33типов. У 3 больных ПЦР не подтвердила наличия ВПЧ: у больного с инвертированной папилломой с признаками малигнизации выявлен вирус Эпштейн-Барр, у 2 больных с гипертрофией язычной миндалины не выявлено признаков наличия вирусов.

Полученные данные подтверждают высокую специфичность морфологических изменений на тканевом и клеточном уровне, вызываемых вирусом папилломы человека. Обнаружение онкогенных типов ВПЧ в множественных папилломах и инвертированной папилломе полости носа указывает на необходимость диспансерного наблюдения и проведения специфического лечения этой группе больных в свете современных представлений о роли ПВИ в возникновении злокачественных новообразований.

\title{
Список используемых источников информации
}

1. Seedat R. Y., Combrinck C. E., Burt F. J. HPV associated with recurrent respiratory papillomatosis. Future Medicine, Future Virology 2013; 8 (5): 477-492.

2. Bodily J., Laimins L.A. Persistence of human papillomavirus infection: keys to malignant progression. Trends in Microbiology 2011; 19 (1): 33-39.

3. Герайн В., Чирешкин Д.Г. Молекулярно-биологические аспекты ювенильного респираторного папилломатоза и его комбинированное лечение. Вестник оторинолар. - 1996. -№4. -С. 3-8.

4. Бойко Н.В., Панченко С.Н. Роль папилломавирусной инфекции в возникновении носовых кровотечений. Рос. ринология. 2001. № 3. С. 9.

5. Бойко Н.В., Панченко С.Н. Локализованное внутрисосудистое свертывание крови у больных с носовыми кровотечениями. Новости оториноларингологии и логопат. 2001 . № 3. С. 5.

6. Бойко Н.В., Панченко С.Н., Кириченко Ю.Г. К вопросу о морфогенезе инвертированной папилломы носа. Российская ринология. 2008. Т. 16. № 3. С. 23-28

7. Бойко Н.В., Колесников В.Н. Хирургическое лечение инвертированной папилломы носа. Рос. ринология. 2005. № 1. С. 29-32.

\section{Гаджаева Н.И., Казаков В.Ю., Муктаров О.Д., Пичхидзе С.Я. Исследование режима ультразвуковой обработки на структуру биологического гидроксиапатита}

\author{
СГТУ имени Ю. А. Гагарина \\ (Россия, Саратов) \\ doi:10.18411/lj2016-4-07
}

Известно, что локальное восстановление поверхности зубной эмали может быть улучшено гидроксиапатитом (ГА) с размером частиц 20 нм, который аналогичен игольчатым строительным блокам эмали. Наночастицы ГА могут адсорбироваться на поверхности эмали и даже интегрироваться в ее естественную структуру.

Целью настоящей работы являлось получение наноразмерной структуры биологического гидроксиапатита (БГА) из костной ткани животных. В работе использовался метод ультразвуковой обработки (УЗО). Были исследованы образцы БГА [1-4] до и после УЗО частотой 22 и 44 кГц методом просвечивающей электронной микроскопии (ПЭМ). Для увеличения стабильности образующихся наночастиц БГА диспергирование осуществляли в растворе ПАВ марки ОП-10 в течение 2-3 минут (рис.1). 